\title{
The Rutherford B. Hayes Memorial Library
}

$\mathrm{O}$

N August 12, 1955, President Dwight

D. Eisenhower approved a joint resolution of the House and Senate of the United States "to provide for the acceptance and maintenance of Presidential libraries, and for other purposes." Thus was created Public Law 373 which gives official sanction to the trend of establishing as separate libraries research institutions of American history surrounding the times of the Presidents of the United States.

The recent fund-raising campaign and ground-breaking exercises for the Harry S. Truman Library in Independence, Missouri, have helped to focus public attention on the subject of Presidential libraries and their place among special libraries.

When a President leaves the White House, he follows the precedent established by George Washington and followed by all his successors in office, taking his correspondence, memoranda, books, pictures, memorabilia, in fact everything except the official papers of his office. In early times the collection numbered but a few thousand items; in recent times, a few million pieces.

The personal papers and records of many early Presidents were scattered or destroyed by the ex-Presidents or by their heirs. A few Presidential collections in whole or in part, have found their way into the Library of Congress.

The heirs of President Rutherford B. Hayes, nineteenth President of the United States, and particularly his second son, Colonel Webb C. Hayes, resisted the several appeals made to return

Mr. Marchman is director, the Hayes Memorial Library. the former President's papers to Washington. Instead, Colonel Hayes sought, with the cooperation of the state of Ohio, to establish a research institution upon the family's estate. With President and Mrs. Hayes' books and papers as a nucleus, the library was to specialize in the period of the former President's life. Colonel Hayes envisioned an institution which would preserve his parents' Americana as well as retain something of the atmosphere of their times.

The first step was to deed to the state of Ohio, as a gift, the historic 25-acre Spiegel Grove in Fremont, Ohio, where President Hayes had made his home after 1873. Then Colonel Hayes offered the Presidential collections. Accepting the library, Presidential diaries, letters, scrapbooks and memorabilia, the state of Ohio appropriated $\$ 50,000$ to build a fireproof building to house the materials in Spiegel Grove. Colonel Hayes contributed an equal amount, and the first wing of the present structure was erected. A structure of classic architecture in gray Ohio sandstone, the building was formally opened to the public on May 30, 1916. It was the first of the separate Presidential libraries to be established. Newton D. Baker, Secretary of War, represented President Woodrow Wilson at the dedication exercises, and all organizations with which President Hayes had been associated sent representatives to take part in the ceremonies.

When the original building was completed, Colonel Hayes discovered that it was not large enough to contain the museum and library he had in mind, or to provide for future growth of the library. Thereupon he contributed funds for the erection of an annex, somewhat larger in 
area than the original building. Construction was well under way by the time of the centenary celebration of the birth of President Hayes on October 4, 1922.

The library and museum building was placed near the Hayes residence in beautiful, wooded Spiegel Grove, facing what was at the time the main entrance to the grounds, a triangular plot covered by a virginal growth of forest trees. The main floor and the basement floor of the library building are reserved for museum displays and offices. The research library, study area and staff offices are on the second floor.

The library of nearly 10,000 volumes accumulated by President and Mrs. Hayes, their correspondence, consisting of some 150,000 or more pieces, their pictures, photographs, maps, scrapbooks, the President's several diaries, and hundreds of personal items were removed from the residence in Spiegel Grove and placed in the new fireproof building. Provision was made to keep intact all the Hayes papers and the personal library during any subsequent growth of the research institution. There followed the mammoth task of organizing, sorting, checking, arranging, cataloging and filing, to provide ready reference for scholars and students.

In the museum, certain aspects of American history and biography are graphically illustrated. There may be seen interesting original letters written and signed by all the Presidents of the United States from the time of George Washington to the present; many personal objects associated with the Presidents, including a pair of gloves of Abraham Lincoln, his slippers, an original handbill of Ford's Theatre for the performance on the night he was assassinated, a book from his private library, The Last Men of the Revolution, and a fine old desk which he used. A collection of American Revolution items, mostly of a military nature, includes leather helmets worn by a private American soldier and a captain, a Hessian helmet, American

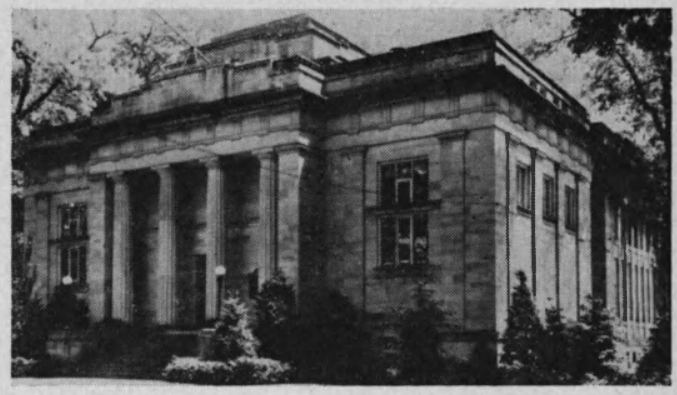

canteens, stirrups, powder horns, and pistols given to President Hayes by Sarah Smith Stafford, of Trenton, New Jersey. Hundreds of souvenirs and memorabilia of President and Mrs. Hayes include the military field equipment used by Hayes as a colonel, later brigadier general, in the Civil War, as well as many other things associated with earlier and later periods of his and Mrs. Hayes' life.

There is the stately old carriage used by President Hayes in Washington and later in Fremont, Ohio. It was used for a time by President Garfield. Many of Mrs. Hayes' elaborate gowns worn at White House receptions, including her simple wedding dress worn at her wedding in 1852, are on exhibition in modern museum cases. Also on display is $\mathbf{a}$ magnificent doll house given to President Hayes' ten-year-old daughter, Fanny, when she was in the White House. There are hundreds of relics of the American Indians presented to President Hayes by Indian delegations to Washington or by Indian agents. The exhibit includes thousands of items gathered from all parts of the world by Colonel and Mrs. Webb C. Hayes: a sizable collection of Chinese and Korean curios, a magnificent weapons collection, and objects from India, the Philippine Islands, South America, Alaska, the Holy Land and the islands of the South Pacific.

The library collections have grown steadily since 1916, and continue to grow daily. At present there are about 60,000 volumes in the research library, thousands of pamphlets and periodicals, an 
important group of maps, a large collection of photographs, prints and pictures, a number of important newspaper files, and a manuscripts division containing more than a half million pieces (the Hayes papers form the nucleus). The library has an expanding department of microfilm, all modern aids to research and writing, and a staff ready to provide the researcher with excellent individual cooperation. More and more students and writers from all parts of the nation are making use of the research possibilities for projects in American history.

The Rutherford B. Hayes Memorial Library is intended to be a research center for the study of American history for the period between the Civil War and the beginning of the twentieth century. Emphasis continues to be placed on every phase of the life and times of President Hayes, and on his special interests and contributions. The library is particularly strong in printed sources on the following subjects: the Civil War; reconstruction in the South following the Civil War; the Spanish-American War; civil service reforms; currency; monetary and prison reforms; Ohio history since 1840; Sandusky (Ohio) Valley history; education, particularly in the South; this history of the Negro and his problems; bibliography; social history; general American biography; the American Indian; American travel and description; and American local history.

The Hayes papers contain: the bulk of correspondence received by the President and Mrs. Hayes during their lifetime; a few thousand copies, or originals, of letters they wrote; the diaries of President Hayes in 28 volumes; his White House notes and memoranda for cabinet meetings; social registers of the White House; several volumes in manuscript of abstracts of letters received by the President between 1877 and 1881; 130 volumes of scrapbooks of newspaper clippings kept during the Hayes administration, as well as numerous other scrap- books of an earlier and later date; proceedings of executive sessions of the Senate; correspondence on Indian affairs; Civil War regimental records of Hayes' regiment; notebooks used for his various political campaigns for Congressman and for the three terms he ran for the governorship of Ohio; and other materials.

The manuscripts division contains also collections of materials about all the Presidents of the United States and the papers of the children of President and Mrs. Hayes, as well as numerous relatives. Sizable groups of papers of interest and significance include: collections of papers of I. H. Burgoon, Mary Clemmer, Governor William Claflin of Massachusetts and Mrs. Claflin, Benjamin Franklin Coates, A. L. Conger, George William Curtis, Andrew E. Douglass, Minnie L. Failing, Gustavus A. Gessner, Murat Halstead, General Russell Hastings, Colonel William E. Haynes, Elizabeth Mitchell Heyl, William Dean Howells, John Little, General James B. McPherson, Warren P. Noble, J. P. Reynolds Company military escutcheons, Dr. John B. Rice, William K. Rogers, Admiral Charles O'Neil, Anne Tressler Scott, John Sherman, William Henry Smith, the Stem family, Colonel F. W. Swift, Dr. James W. Wilson, and many others.

The microfilm files include: copies from public and private depositories of papers of many of Hayes' contemporaries, important newspaper files for the Hayes period, the official records of the Hayes gubernatorial administration in Ohio, and several hundred rolls of film representing the first step in collecting at the Hayes library the records created by the Hayes administration in Washington.

To the south of the library and museum building is the Hayes homestead, a stately mansion surrounded by majestic old trees. The home, preserved and maintained privately, is still the residence of President Hayes' descendants and not open to the public at any time. It was built in $1859-60$ by Sardis Birchard, 
bachelor uncle and legal guardian of Hayes, as a summer home for his nephew. The old trees surrounding the house bear the names of well-known men who have been guests at Spiegel Grove.

Along the southern ridge of the Spiegel Grove estate, for nearly a half mile, winds a famous old Indian trail, the Sandusky-Sioto route, traversed by the Indians before white settlement and later used by General William Henry Harrison as a military supply route during the War of 1812. By the side of the trail, on a quiet wooded knoll and enclosed by an iron fence, is the monument of Vermont granite marking the final resting place of President and Mrs. Hayes.

At each of the six entrances to the Spiegel Grove estate are impressive iron gates that once guarded an entrance to the White House grounds before and during the Hayes administration.

The Rutherford B. Hayes Memorial Library and the Spiegel Grove estate are operated jointly by the state of Ohio, through the Ohio Historical Society, and by the Rutherford B. Hayes and Lucy Webb Hayes Foundation, founded in 1921 by Colonel Webb C. Hayes. The state provides for the care and maintenance of the grounds and the library and museum building and provides most of the physical improvements. The Hayes Foundation is interested in the use of the resources and improvement of facilities for research and investigation in American history. The growth and development of all branches of the library are supported by the foundation, collections are acquired to improve the resources, and library equipment added when needed.

Recently the trustees of the Hayes Foundation have authorized a program of publication of source materials of American history, principally from resources in the manuscripts division of the
Rutherford B. Hayes Memorial Library, in keeping with the recommendations of the National Historical Publications Commission, suggesting that the Hayes correspondence and papers be published.

Several books have been published during the past few years in which the authors have acknowledged research aid received from the Rutherford $B$. Hayes Library. The most extensive recent use of the source materials in the library was made by Harry Barnard in writing his Rutherford B. Hayes and His America (1954).

Authors of other recent books making use of the manuscript resources of the library include J. J. Perling, Presidents' Sons (1947); Hampton M. Jarrell, Wade Hampton and the Negro: The Road Not Taken (1949); Jessie Pearl Rice, J. L. M. Curry: Southerner, Statesman and Educator (1949) ; Bess Furman, White House Profile (1951); Holman Hamilton, Zachary Taylor: Soldier in the White House (1951); C. Vann Woodward, Origins of the New South (1951) and Reunion and Reaction: The Compromise of 1877 and the End of Reconstruction (1951); T. R. Hay, James Longstreet (the Politician) (1952); Bell I. Wiley, The Life of Billy Yank, the Common Soldier of the Union (1952) ; James H. Rodabaugh, editor of The Governors of Ohio (1954); and M. B. Schnapper, The Grand Old Party, the First Hundred Years of the Republican Party: A Pictorial History (1955).

Numerous dissertations and theses have been written from resources in the library, and there is usually one or more in progress every year.

The library maintains a prompt and liberal interlibrary loan service for its books. Its printed resources are included in the union catalog of the Library of Congress and the regional union catalogs located at Cleveland and Columbus, Ohio. 